\title{
MADRASA AND ITS DEVELOPMENT IN NIGERIA
}

\author{
Abdullahi Ibrahim Sani \\ Academy of Islamic Studies, University of Malaya, Malaysia \\ 0603 Kuala Lumpur, Selangor, Malaysia \\ Email: binabdullah008@gmail.com
}

\section{Cecep Anwar}

Department of Islamic Education, Faculty of Education and Teacher Training, UIN Sunan Gunung Djati Bandung

Jl. A. H. Nasution No. 105, Bandung, Indonesia, 40614

Email: cecepanwar@uinsgd.ac.id

Received: 09, 2020. Accepted: 12, 2020. Published: 12, 2020

\begin{abstract}
This study aims to describe the development of madrasa education system in African continent. It also explores the development of madrasa in Taraba State, Nigeria. This research used a descriptive method. The results showed that in African continent, madrasa institutions had their historical developments, financial support and how British colonial influenced their development. In Nigeria, madrasa institutions have had similar developments with their counterparts from other countries in the African continent. British colonialism has reduced the supremacy of madrasa in terms of financial and managerial capacity. In Taraba State, Nigeria, there are several different forms of traditional non-formal Islamic education. Their forms include madrasa qur'anic college with the evolutionary development around Alaramma; madrasa whose mobility is limited; and Islamic school. The three educational institutions are recognized by the government and they have experienced modernization in terms of their management for the Qur'an program and their Western infrastructure use.
\end{abstract}

Keywords: Madrasa Development, Nigeria, Religious Learning, Traditional Learning

\section{ABSTRAK}

Penenlitian ini berutujuan untuk mendeskripsikan perkembangan sistem pendidikan madrasah yang ada di Benua Afrika dan mengeksplorasi perkembangan madrasah di Negara Bagian Taraba, Nigeria. Penelitian ini menggunakan metode deskriptif. Hasil penelitian menunjukan bahwa di Afrika, madrasah memiliki perkembangan dalam sejarah, dukungan finansial dan pengarub kolonial Inggris. Madrasah di Nigeria memiliki perkembangan serupa dengan negaranegara lain di benua Afrika. Kolonial Inggris telah mengurangi supremasi madrasab dari aspek kemampuan keuangan dan manajerial. Di Negara Bagian Taraba, Nigeria, ada beberapa bentuk. pendidikan Islam tradisional non-formal yang berbeda. Pertama, dalam perkembangan evolusioner Madrasah Qur'anic College yang berkembang di sekitar Alaramma. Kedua, madrasah yang mobilitasnya dibatasi. Ketiga, sekolah islamiah. Ketiga lembaga pendidikan tersebut diakui oleh pemerintah dan telah mengalami modernisasi dalam pengelolaannya, untuk program al-Qur'an dengan menggunakan infrastruktur Barat.

Kata Kunci: Nigeria, Pembelajaran Tradisional, Pendidikan Islam, Pengembangan Madrasah 


\section{INTRODUCTION}

Madrasa education is one of the systems of education developed in many countries like Nigeria. It refers to traditional islamic education institutions. In most African countries, it is usually used to be a locally built camp or hut at the outskirt of the city or town, where the teaching and learning of madrasa education are observed. This traditional Islamic education institution has been in existence in northern Nigeria before the emergence of the British colonialist, in the $18^{\text {th }}$ century (Shehu, 2006). Its existence has been felt by the society before the arrival of colonial. Madrasa has its roots in some African countries, such as Timbuktu (in Mali), Chad, Ghana, Niger Republic, and Senegal (Shehu, 2006). They have developed centuries and undergone several changes to survice in the continent.

Madrasah institutions are important religious and cultural tool to socialize the processes and continuity of Islamic education and traditions in Muslim societies. They play crucial roles in the early time for Muslim children. They train and educate children reading and memorization of the glorious Qur'an which is fundamental to their understanding of the faith and performance of routine acts of worship. They also provide early training in Islamic manners and etiquettes leading to the development of children development and personalities that will equip their productive lives on earth and in the hereafter. To achieve this purpose, Qur'anic schools has been accepted by the society to serve children Muslim. Religious education is considered a religious obligation. These Islamic education institutions prevailed in much of northern Nigeria as the sole institutions that were designed for religious learning long before the advent of western education and colonization emerged (Ozigi \& Ocho, 1981). The society has never witnessed the transformation or modification of the institution of madrasa with western and modern school concept before the arrival of colonial.

The heyday of madrasa was challenged by the advent of western education. Madrasa dominant system in Islamic education with the necessary institutional support and protection began to deteriorate in the African countries. They are left without any state support and began to dwindle and stagnate (Umar, 2003). These schools were subsequently characterized by limited curricula goals and contents; weak management structures; a poor resource base; and lack of official recognition of both their products and form of learning. As a result, Islamic education institution at that time became increasingly incapable of helping learners to achieve selffulfillment and effectively discharge their civic responsibilities as citizens of an emerging nationstate

In Taraba state, Nigeria, there are several distinct forms of non-formal traditional Islamic education. The first, in terms of evolutionary development, is the Madrasa Qur'anic College. This type of Islamic education institution is nomadic in nature and could not reside longer in a particular place to serve the students. It revolves around the Alaramma, the teacher, who often travels with the pupils and pitch a camp often on the outskirts of the town to form a collegiate system for the total study of the Qur'an. Second, Madarasas where the mobile nature of the schooling system has been restricted - often an Alaramma could stay in the same place for years. The third is the Islamiyya Schools that are recognized by the Government and have been undergoing modernization in terms of its management to run Qur'anic schools program using Western infrastructures. They are recognized by SUBEB (State Universal Basic Education Board) and receive some assistance from the government. The assistance can be in form of financial support to help them survive and meet their need.

Islamic education institutions have emphasized the teachings of the Glorious Qur'an and it became a clear guideline leading to the steady progress and subsequent development of Islamic education. The companions had played a major role in achieving this objective. Thus, under Umayyad, Abbasid, and other subsequent regimes, Islamic education institutions had developed, and reached different corners of North and West Africa, including Hausa land eventually Taraba 
State. This development provided many socio-religious benefits for the teachers as well as and students in the Islamic education institutions. In addition to teacher and students, the society also receive benefits from the madrasa development for their children religious development.

In relation with Islamic education institution development, Brunei Darussalam country has applied Islam as an official religion. In this country, Quranic schools enjoy full-fledged state intervention. This is to say that the establishment and maintenance of religious institutions are the responsibility of the government. To fulfill this, the government establishes eloquent structures for Islamic schools. For example, Tabfeez al Qur'an institutions have been supported by the provision of hostel accommodations, classrooms, toilets, playground, and mosques. Some of the renowned Islamic institutions in the Sultanate include: Brunei college of Islamic Studies (Ma'ahad), Religious Teachers Training college and Sultan Haij Hassanal Bolkiah Tahfeez. al Qur'an Institute (Yousif, 2000). Those institution receive all support both financially and structurally from the state to develop and strive in delivering Islamic education.

Another country in Southeast Asia, Indonesian government has also supported madrasa institutions. They enjoy the same treatment as the conventional schools because they are both recognized and supported by the government. For instance, those students who memorize Qur'an by heart (Huffaz) are certified by the government of Indonesia as a form of the government recognition and appreciation. Those buffaddz and therefore employable in schools and mosques to secure their employability for their life (Muhammad \& Hashim, 2014). This is different from Nigeria where the country has not recognized the Qur'anic schools and not certified buffadz for their achievement. The condition makes it difficult for the students to work for their living. Without proper and better support from the government and the society, those students in Nigeria have weak motivation to strive in their expertise.

In Malaysia, Qur'anic schools popularly referred to as Ma'abad Tabfeez al Qur'an, also receive some funds from the government. In addition the Islamic education institution have received financial assistance from the Zakat administrators to run the institution. The government applies Islamic religion as the state foundation. The state is involved in the provision of infrastructure and development of religious education. Ma'ahad Tabfeez, al Qur'an institutions are built and run by the government (like the madrasa school in Kedah, Selangor, and many other places). Given this circumstance, Madarasab institutions fall under the category of organization that could access Zakat funds in Malaysia (Yusoff, 2013). Access to this financial source provide the strength for the institution to serve and maintain the quality of Islamic education for the students.

There is a little information on how Islamic education institution in Nigeria developed and how those institutions position in relation to the state and government assistance. This study was aimed at investigating the development of madrasa institutions in Taraba State, Nigeria. In addition, their status and how their financial condition to run religious education are explored.

\section{METHOD}

This study was aimed at investigating the development of Madrasa in Taraba State, Nigeria. To achieve the objectives of the study, descriptive qualitative was applied. The data were collected through document analysis and observation. The former deals with the book, university record journal, and report relevant to the data needed. The latter has something to do with observation of activities related to the madrasa system implementation.

\section{RESULTS AND DISSCUSSION}

Based on the data collected, this study has several findings. The findings will be organized as follows: Madrasa in Africa, Madrasah in Nigeria and the development of condition of 
madrasah in Taraba State. Those findings will be discussed with relevant literature to see how this study contributes to the body of knowledge.

\section{Madrasa in Africa}

Islam has spread to several states such as Libya, Egypt, Morocco, Tunis, and Algeria in North Africa, to West Africa south of the Sahara (Bakewell \& De Haas, 2007). The factors which pioneered and facilitated the spread of Islam religion were the Sufi orders, Muslim visitors, the itinerant scholars, the traders, and Muslim reformers. They served as teachers, promotors of literacy in Arabic script and language, and they taught Islamic sciences in general. When Islam was introduced to Kanem Borno and became a state religion, Bornu gradually became the center for Qur'anic recitation more than any other town in Hausaland as Qur'anic teaching and recitation became its specialty. This fact was attested by Muhammad Bello, the son of Shehu 'Sheikh Othman bin Fodio (Yola, 2002).

The madrasa system enjoyed great support and encouragement from the Mais (a title for Bornu rulers) (Shehu, 2006). The system has produced religious reformers, rulers, clerics, and scholars, administrators, judges, and a sequence of men who are literate and have good command in the Arabic language (Taiwo, 2013). Madrasa originated in the reign of (Mai) Ali Gaji (1503 C.E) who encouraged and supported the establishment of such centers in many areas for the spread of literacy. The prominent figures include Geidam, Damaturu, and Kukawa. These Islamic education centers produced several experts in the writing and recitation of the Qur'an. The Mais supported and generously financed these Qur'anic schools and their scholars. It influences the Qur'anic school system in Bornu which spread to the neighboring Hausa states.

After successfully conforming the political, social, religious, economic, and intellectual life of Hausa land to Islamic teachings, the Mujaddid Sheikh Othman bin Fodio instructed all the students of Al-Qur'an to disperse of the Caliphate and impart their knowledge in order not to remain idle on the one hand. On the other hand, this program was trying to rescue the populace from continuously wallowing in the river of ignorance. These people comply with the orders of the Shehu. They started gathering students for this purpose. Parents then regarded it as their contributing quota to hand over their wards to the Mallam. It enhanced the jihad by having children learned in the Qur'an who would successfully carry out the responsibilities of the future generation under the teachings of Islam (Maibushra, 2005). The teachers then along with their students were adequately catered for as per their feeding, accommodation, and security. Rulers were extremely happy to host these types of schools and regarded it as a religious duty to shoulder all their responsibilities, in addition to the support rendered by the society. Begging and destitution in this system of education were then unheard of as their principal remote cause, governmental and societal neglect were not in existence.

Jihad leaders continued to spread and encourage this system of education. One of the known figure that play prominent role, is Shehu 'Abdullahi bin Fodio. He brought the pronunciation of Arabic letters close to their similes in Hausa and Fulfulde. For example,

1. (ق) in Arabic language is uttered as $\{K\}$ in the indigenous language (Hausa/Fulfulde)

2. (b) in Arabic language is uttered as $\{\mathrm{D}\}$ in the indigenous language (Hausa/Fulfulde)

This contribution helped greatly in making pronunciation of Arabic letters easy among the learners in Hausa and Fulfulde. It has been maintained among population and continued to be practiced by the speakers our present time (Imam, 2002).

According to the National Council for the Welfare of the Destitute (2001) and (Okugbeni, 2013), the madrasa system of education has been in existence, centuries before British colonizers, and it has been the source of moral and educational training, to northern Muslim dominated societies in Nigeria. Before the coming of the British colonial powers, in the year 1824, every family sent their children to Quranic school, popularly known as makarantar allo 
meaning 'the slate school', (referring to the wood curved object that the Quran verses and chapters are hand-written and recited). Children left their homes and went to school. They returned home when the school hour is over. They lived with their parents and received moral upbringing and directions for further steps in life (Kabir, Iliyasu, Abubakar, \& Ahmad, 2005).

Quranic schools or madarasa predated British colonialism in Nigeria. In most parts of West African states, the school's program went through a couple of modifications especially during the Elkanemi dynasty. In this era, the Qur'anic educational system was referred to as madarasa system and was based on the doctrine of migration (Hijra). In the pre-colonial era, Qur'anic schools have been considered to be the responsibilities of government, state treasury through Zakat fund (received from the rich people), parents of the pupils and people in the communities also readily supported the Almajiris who came from faraway towns. In return, the teacher and the students engaged in helping the community through cultivating their farms, laundry, gardening, weaving, sewing, and so on to contribute to the society that assisted them. This is different from the Tsangaya school system. The system beg in the streets and public places and they had never been a chore of the early Almajiris (Abdulqadir, 2003; Odumosu et al., 2013).

Madrasa as an Islamic education institution is one of the systems of education developed in several countries like Nigeria. In most African countries, it is usually built in the city or town. The activities of teaching and learning in Madrasa are usually held. This traditional Islamic education institution has been in existence in northern Nigeria before the emergence of the British colonialist, in the $18^{\text {th }}$ century (Shehu, 2006). Its contribution to the society where they exist have been felt and it was before the arrival of British colonial. Madrasa has its roots in some African countries, such as Timbuktu (in Mali), Chad, Ghana, Niger Republic, and Senegal (Shehu, 2006). They have developed centuries and undergone several changes to survice in the continent.

\section{Madrasa in Nigeria}

The traditional system of Arabic Islamic education otherwise known as the madrasa system, in Nigeria, covers four categories which can be divided into three main phases (Gbadamosi, 1978). The first phase began at the early age of about five when the young Muslim children are sent down to the piazza schools managed by some mallams (i.e. teachers). The pupil, according to Gbadamosi, could be in this long but crucial stage for about four to seven years. In such a setting, a single mallam could have as many as forty pupils some of whom might attend the schools regularly. In some of the schools, the teachers were not paid as there are no school fees or special levies (Gbadamosi, 1978). This indeed was the case in the informal setting where the Arabic teachers normally had their vocations such as farming, weaving e.t.c., to support themselves. This study found that even though they were professional teachers and clerics, they drew no salaries from the conduct of these schools. They rely only on the various gifts and alms which the parents of their wards might send them from time to time (Gbadamosi, 1978)

In Nigeria, madrasa system received information on private enterprises around traditional Islamic education. Such personal efforts as made by individual Muslims culminated in the establishment of Madaaris in various parts of the country. That explains why individual ownership of such schools prevailed more than community ownership. Most of the notable traditional Arabic schools in Nigeria are identified with some leading Islamic scholars and personalities in the country. For instance, the Al-Mabad traditional Arabic school that later developed into the Shariah College of Kano was founded in 1934 through the individual effort of Shaykh Nasir Kabara. Similarly, the effort that led to the founding of an Arabic School known as Al-Mahad al-Azhari of Ilorin, since 1947 is associated with Shaykh Kamalu-d-din Al-Adaby. In a similar token, the founding of Markaz-ut-Ta'limil Arabyyi in Abeokuta in 1950 and later in Lagos in 1952, both in the southwestern part of the country, was attributed to Shaykh Adam Abdullah Al-Ilori. In the same manner, Al-Mahadal-Arabyyi founded in Ibadan, in the 
Southwestern part of the country in 1957, was a product of an individual effort by Shaykh Murtadha Abdus-Salam. This is the situation with several other Arabic schools in the country.

In addition to the prevalence of individual ownerships for Islamic education institutions, there are few institutions which were established through joint action or community efforts. For instance, Olurode found that two of the 21 traditional Arabic schools studied in Epe, admitted of some substantial community participation (Van Bruinessen, 2008). He added that these were mainly the results of youths' activism' because, in an attempt to give a competitive start to their children, Muslim youths have come together in Epe, Iwo and Ilorin to influence the direction of madrasa (Gbadamosi, 1978). In Ilorin, however, individual ownership was prevalent community participation in the founding of madrasa. The involvement of parents' among other stakeholders could be recognized and appreciated by inviting them to the board to serve as advisers (Gbadamosi, 1978).

Individual ownership was prevalent in Iwo too. This study found that "most sole proprietors of madrasa had resisted past attempts by communities to be involved" (Babajo, Jamaluddin, \& Hamid, 2017). In Lagos where most Arabic schools are owned by individuals, the Jamat-ul-Islamiyyah of Nigeria operates what could be regarded as a good example of community-owned madrasa, as classes are tuition-free for teachers are paid by the Jama'ah (Gada, 2010).

There is a political dimension for maintaining as custodians of the madrasa schools (Emirs and the Sultan) as figureheads. This political dimension is contrast with the role of executive leadership style they were used to. The emir's power to issue state grants and approved all the expenditures was taken over by the British resident commissioner. In a secular system, the British government did not consider Qur'anic schools and did not take into consideration their respected teachers as part of state responsibilities. Most of the emirs were either killed or deposed and replaced with the British representatives (AbdulQadir, 2003; Abdulqadir, 2014; Shehu, 2003; NCWD, 2001). Consequently, the Qur'anic teachers and their Almajiris had to look for an alternative way for their survival to run and serve students in learning Islamic education. In a nutshell, they lost all the privileges under the colonial administration.

Islamic education institution faced worse situation. The duty of running the education was transferred to the Resident commissioners. The tax was also introduced generally, and the Qur'anic teachers were forced to pay the tax. This was new experience for them since they did not pay the tax in the past. This pressing situation had made the teachers to move from one place to another to avoid the tax. For the teachers, staying a complete year in one place would warrant paying the tax to the British colonial. To avoid tax paying, the Qur'anic teachers and their pupils moving from one place to another. Their nomadic condition had influenced their Qur'anic literacy. This is to say that the more they avoid tax paying, the more they move from one place to another. This situation influenced the students' performance in learning (NCWD, 2001).

The abolition of Zakat and Mahren (state treasury) for madrasa had led to difficult situation. They were without any doubt the economic strength for madrasah. The Qur'anic teachers was influenced by this unfortunate financial condition in Islamic education system. Mahren was a state bank where all the government wealth collected from the community are kept for running the affairs of the state. British colonial administrators did not assist financially Qur'anic education institution. It refused to assist or finance the madrasa Qur'anic education (Shehu, 2003). Furthermore, they relegated the use of Arabic alphabets to inscribe the local language (Ajami) as a means of communication in Hausa, by replacing it with the English alphabets and Roman figures. This policy had carried bad impact to the Tsangaya teachers who were considered the most educated elite because they served the public and the government. 
Changing the written form of Ajami as a means of public and government communication had made traditional scholars officially illiterate and therefore, they were redundant (NCWD, 2001).

The missionaries were the first to import formal education in Nigeria. They combined formal education with the Bible (Christianity). Their effort had been rejected by the people of northern Nigeria who desperately reject secular education in the early period. Odumosu et al. (2013) and NCWD (2001) posit that the colonialists using their power, stablished and imposed the new system of education, with the intent to rival Qur'anic education. The newly introduced system straight away obtained fame and superiority because it enjoyed government backing. The graduates of the formal schools took the center stage in management, statesmanship, social work, and institutions. This was the beginning of the failure and regression of the Almajiri Qur'an educational institution.

Table 1.1 Structural Settings and Pedagogy Stages of Madrasa School System

\begin{tabular}{|c|c|c|c|}
\hline Stage & $\begin{array}{l}\text { Chronology } \\
\text { Ranks \& Title }\end{array}$ & Age & Lesson \\
\hline $\begin{array}{l}\text { Mimicking } \\
\text { Stage }\end{array}$ & Kolo & $4-5$ & $\begin{array}{l}\text { This is the beginner stage. A newly admitted child } \\
\text { usually listens to the recitation of others. } \\
\text { Eventually, he gets used to the rhythm of a } \\
\text { particular recitation and starts mimicking. The } \\
\text { Mallam observes each student carefully and as } \\
\text { soon as he notices that the child starts mimicking } \\
\text { the recitation of others, he moves him to the next } \\
\text { stage }\end{array}$ \\
\hline $\begin{array}{l}\text { The Biyawa } \\
\text { Stage }\end{array}$ & Titibiri & $6-7$ & $\begin{array}{l}\text { This stage is characterized by the student reading } \\
\text { after the teacher. He is taught the opening phrases } \\
\text { of the Qur'an first. The teacher reads to the } \\
\text { student part by part so that the latter can easily } \\
\text { read after the teacher. For example; } \\
\text { A'udhu---Billabi---Minash Shaitanir---Rajimi } \\
\text { Bismillahi---Ar Rahmani---Ar Rahimi---,etc }\end{array}$ \\
\hline $\begin{array}{l}\text { The Babbaku } \\
\text { Stage }\end{array}$ & Gardi & $7-10$ & Arabic alphabets \\
\hline $\begin{array}{l}\text { The Farfaru } \\
\text { Stage }\end{array}$ & Malam & $11-15$ & $\begin{array}{l}\text { Joining the alphabets to make a word. The student } \\
\text { is taught by the correct pronunciation of each } \\
\text { letter along with its accompanying vowel }\end{array}$ \\
\hline Haddatu & Alaramma & $16-18$ & $\begin{array}{l}\text { Memorization of the Glorious Qur'an. When the } \\
\text { entire written portion is memorized by the student } \\
\text { comes to the teacher and conducts a memory test, } \\
\text { which is called Hadda. The teacher withdraws the } \\
\text { allo and holds it away from the sight of the student } \\
\text { while the latter reads out the withheld portion } \\
\text { from memory }\end{array}$ \\
\hline $\begin{array}{l}\text { The Rubutu } \\
\text { Stage }\end{array}$ & Gwani & $19-25$ & $\begin{array}{l}\text { This is the stage at which the student starts writing } \\
\text { for himself and no longer relies on the teacher for } \\
\text { that. }\end{array}$ \\
\hline $\begin{array}{l}\text { The Zurfi } \\
\text { Stage }\end{array}$ & Gangaran & $\begin{array}{l}26- \\
\text { above }\end{array}$ & $\begin{array}{l}\text { This is the stage at which the student is allowed } \\
\text { for the first time to hold the complete copy of the } \\
\text { Qur'an and henceforward use it for writing on his } \\
\text { Allo (wooden slate) }\end{array}$ \\
\hline
\end{tabular}

The above seven stages go in line with the category of the pupils and pedagogies which in most cases was based on their ages. 
Table 2.1 Distinction between Conventional and Madrasa School.

\begin{tabular}{|c|c|c|}
\hline Items & Modern School & Madrasa School \\
\hline $\begin{array}{l}\text { Student's } \\
\text { Accommodation }\end{array}$ & $\begin{array}{l}\text { Established Structures with } \\
\text { classrooms and offices }\end{array}$ & $\begin{array}{l}\text { Lessons are run in a small } \\
\text { room, under the tree, open } \\
\text { space, and uncompleted } \\
\text { buildings }\end{array}$ \\
\hline Subjects taken & $\begin{array}{l}\text { English, Maths, Computer, } \\
\text { primary science, IRK, Arabic, } \\
\text { Social Studies, Physical and Health } \\
\text { Education, civic education }\end{array}$ & Qura'nic Recitation \\
\hline Wages and Salaries & Government Responsibilities & Donations, Charity, Handouts \\
\hline $\begin{array}{l}\text { Teacher's } \\
\text { Educational } \\
\text { Qualification }\end{array}$ & $\begin{array}{l}\text { Minimum Qualification of } \\
\text { National Certificate in Education } \\
\text { (NCE) }\end{array}$ & $\begin{array}{l}\text { No restrictions on paper } \\
\text { qualification }\end{array}$ \\
\hline Teaching Guideline & $\begin{array}{l}\text { Curriculum, Scheme of work, } \\
\text { teacher's lesson plans. }\end{array}$ & $\begin{array}{l}\text { Categorization of Qura'nic } \\
\text { chapters into units }\end{array}$ \\
\hline School fees & $\begin{array}{l}\text { Officially free, but recurrent } \\
\text { expenses for learning materials and } \\
\text { uniforms are paid by parents }\end{array}$ & Free \\
\hline $\begin{array}{l}\text { Levels and duration } \\
\text { of Study }\end{array}$ & Six years from primary one to six & $\begin{array}{l}\text { Five stages. No specific time for } \\
\text { graduation }\end{array}$ \\
\hline
\end{tabular}

Source: National Council for the Welfare of the Destitute (NCWD) (2001).

Madrasa or traditional Islamic education system was designed to build in young minds, to teach doctrines of Islam, as specified in Qur'an. Essentially, it was meant to teach children basic spiritual, moral, and social values to enhance their sense of responsibility. It was also meant to inculcate them the value of caring for those in need. That was why they were made to live on the goodwill of people, who freely donated for their survival. In the original madrasa system of education, the sole objectives of the education were intellectual and moral training as well as life-long discipline for students to achieve.

This study found that there are some challenges facing the madrasa in Taraba State, Nigeria. The madrasa are fully private institutions. The graduates of these Qur'anic schools are the ones who open and run the institutions in their intuition and resources. There is no certificate to attest to the mastery of the subject matter or procedure of testing the knowledge of the prospective Qur'anic teacher before he embarks teaching Qur'an.

Muhammad et. al. (2013) argued that a single teacher was scheduled with a bunch of responsibilities, as the sole proprietor of the madrasa school, to set up a control and run them, with the obligation of shelter, feeding, and clothing of the pupils reverted to him. Initially, the children were made to work on the teacher's farm, but later farming became a difficult task, and the little payment that the teacher receives through the weekly donations from the children's parents could not take care of the enormous responsibilities rested on the teacher. Pupils were made to pay daily stipends for their lessons; to get the little fees the pupils must carry out some menial jobs in public places and hotels, markets, etc. The Almajiri pupils thus neither acquire their educational obligations, as well as their material demands. They often grow up into illiterate adults, poverty-ridden, and uncreative (Hoechner, 2013; Odumosu et al., 2013; Salisu Shehu, 2006).

NCWD (2001) asserts that the madrasa schools lost official patronage, and its graduates were gradually made redundant. Graduates of the British schools were the only ones employed and paid efficiently in government offices. Arabic ceased to be the official language while Roman alphabets were introduced as a substitute. Within a short period the whole northern Muslim communities were termed illiterate (Kabir et al., 2005; Salisu Shehu, 2006). Kabir et. al. 
(2005) further observed that the policies targeted the traditional madarasa Schools and substituting them with secular education. This led to protests, people began to give out their children in trust, to the madrasa schoolteachers in other villages, or its outskirt to teach them Qur'an. Consequently, the madrasa schoolteachers travel, with their pupils in search of a conducive place to settle and teach their pupils in a different environment.

Madrasa institutions play important role in religious and cultural dimension. They serve as a tool to socialize the processes and continuity of Islamic education and traditions in for younger generation in the society. They also provide early training in Islamic manners and etiquettes leading to the development of children development and personalities that will equip their productive lives on earth and in the hereafter. Religious education is considered a religious obligation for parents and society to teach their children. These Islamic education institutions prevailed in much of northern Nigeria as the sole institutions that were designed for religious learning long before the advent of western education and colonization emerged (Ozigi \& Ocho, 1981). The society has never witnessed the transformation or modification of the institution of madrasa with western and modern school concept before the arrival of colonial.

\section{The Challenges of Madrasa in Taraba State, Nigeria}

This study found out that madarasa had faced a variety of challenges right from the period of colonialism to date because of nonchalant attitudes shown towards its progress right from the onset of colonialism to the present democratic dispensation.

\section{Pre-Colonial Madarasa in Taraba State}

The Qur'anic educational system which was believed to be in existence in Taraba StateNigeria, in the early 15th century, can be said to be the backbone of socialization and educational development. Before the advent of the British colonizers, people in northern Nigeria can read and write Qur'an, Arabic language, as well as use Arabic letters to communicate in their local dialect. In the pre-colonial era, the Islamic religion was more prominent in the political and social life of Muslims in Taraba State, and Qur'anic education has been more relevant (Muhammad et. al., 2013; Odumosu et. al., 2013). Muhammad et. al. (2013) and Kabir et. al. (2005) agreed that in most parts of West Africa, the Qur'anic schools precede the coming of the colonialists. Historians agreed to the formation of Qur'anic institutions to be at the beginning of the eleventh century (Odumosu et. al., 2013).

Madrasa schools in Nigeria, particularly in Taraba state are in dire need of redress. The schools housed millions of what can be termed as out of school children. The children are isolated from their parents, in their early lifetime (4 years and above), where they are brought into a new environment and lack all the basic needs of life, like food, shelter, toilets, and basic health facilities. Children beg for food on the streets or from house to house, they have no hostel to sleep in, neither do they have a place for conveniences.

The current challenges of the madrasa system of education started with the invasion of the British colonial powers. When they captured the territories, they killed those emirs who refused to willingly surrender to the British colonial army, some emirs were deposed. Consequently, the emirs lost the powers to control their territories and accepted the new terms of reference to serve the colonial powers as figurehead traditional rulers. The control of the Almajiri school system was also lost. Eventually, the funding of the Almajiri system was stopped on the basis that the schools were religious bodies and therefore they deserve no funds from the government (Taiwo, 2013 and NCWD, 2001).

Abdulqadir (2003); Odumosu et al. (2013) and NCWD (2001) pointed out that when the Tsangaya system could not gather support from the colonial powers, the people of the community, and the disabled emirs, the system collapsed. The British colonial powers introduced their formal education and funded it accordingly. The Almajiri pupils and their teachers were forced to look for other means of survival whereby they resorted to begging and 
doing other menial jobs to survive. This reason is, without doubt, the beginning of the present predicament of the Almajiri system of education in Nigeria.

Hoechner (2013); Kabir et al. (2005); Odumosu et al. (2013), and Fuseini (2016) observed that the fundamental problem facing the madrasa pupils is the absence of food, indecent accommodation, and health facilities, as well as parents deprivation, some of whose parents stay hundreds of kilometers away from the school. Almajiri's consolation is embedded in the belief that all tragedies encountered during this school system would amount to exalted rewards in the hereafter (Heaven).

According to Yusha'u et al., (2013) and Shehu (2006) there was no organized procedure, in the enrollment of the pupils of the madrasa school, unless the eccentric procedure of handing over pupils to the teacher, who would then continue to oversee the academic development of the child. Another amazing fact is that, under this system, one teacher can register 100-200 pupils under his custody. He received no support from the parents, government, or society, and has no plan for health care facilities, shelter, or food. Under this condition, the only alternative option left for them is to take the children to the streets. Madrasa system has been relegated and abused, to the extent that the pupils roam the street picking remnants of contaminated leftover food from the garbage (Yusha'u et al., 2013).

Muhammad et. al. (2013) and Otu (2006) argued that most of the madrasas are dropped at their boarding school without provisions; their parents gave them puny stipend that would hardly last for a week but expected them to live in the school for years. This is what is gradually exposing them to health hazards child abuse, secrets cults, and other sorts of social vices. Hoechner (2013) and Yusha'u et. al. (2013) supported the view and lament that, since the parents of the students are dominantly poor, they used to feel relieved by sending their children to the madrasa boarding school where the children struggle to take care of themselves.

Early Qur'anic education has been an essential part of the socialization process of every child. Parents enroll their children with a community-based Qur'anic School, whereby at graduation, a child is expected to master the ability to recite the Glorious Qur'an, read and write Arabic scripts.

The heyday of madrasa was challenged by the advent of western education. Madrasa dominant system in Islamic education with the necessary institutional support and protection began to deteriorate in the African countries. They are left without any state support and began to dwindle and stagnate (Umar, 2003). These schools were subsequently characterized by limited curricula goals and contents; weak management structures; a poor resource base; and lack of official recognition of both their products and form of learning. As a result, Islamic education institution at that time became increasingly incapable of helping learners to achieve selffulfillment and effectively discharge their civic responsibilities as citizens of an emerging nationstate.

In Taraba state, Nigeria, there are several distinct forms of non-formal traditional Islamic education. The first, in terms of evolutionary development, is the madrasa qur'anic college. It developed and existed around the Alaramma, the teacher, who often travels with the pupils and pitch a camp often on the outskirts of the town to form a collegiate system for the total study of the Qur'an. Second, madrasa where the mobile nature of the schooling system has been restricted - often an Alaramma could stay in the same place for years. The third type of this Islamic eduction institution is the Islamiyya Schools. They are recognized by the Government and have been undergoing modernization in terms of its management to run Qur'anic schools program using Western infrastructures. They are recognized by SUBEB (State Universal Basic Education Board) and receive some assistance from the government. The assistance can be in form of financial support to help them survive and meet their need. 


\section{CONCLUSION}

Based on the findings of this study, there are several things to conclude. The traditional arrangement of the madrasa makes their graduate irrelevant or unemployable because the madrasa does not contain the western type education subjects in the curriculum. Madrasa contains only the recitation and memorization of the Qur'an, and various Arabic and Islamic studies subjects. The problem in madrasa's lifestyle is their exposure to various social and physical dangers. Psychologically, the living condition of the children features a sense of mediocrity, overdependence on immediate society, rejection from other children, and all sorts of negative socio-economic and psychological tendencies.

This paper recommended that the constant Public awareness campaign is necessary to educate the parents that dump their children in madrasa so that they can take good care of them and enroll them in the nearest modern madrasa. On the other hand, governments at all levels (Federal, State, and Local governments) should put heads together to find the consistent ways that would help to reverse, the complete financing and administration of these madrasas. By creating avenues that will enhance popular economic growth, suppress the poverty level among the rural dwellers who are the people patronizing the madrasa. Lastly, governments, other stakeholders, and individual philanthropists should endeavor to build multiple modern madrasa in all the local government areas of Taraba State where they are needed the most, where the students and graduates of madrasa should be taught relevant formal education and skills so that they can be employable after graduation.

\section{ACKNOWLEDGMENT}

The authors would like to thank the University of Malaya for the research grant for that has been partially used for this study. Grant No: ST018-2019.

\section{BIBLIOGRAPHY}

Abdulqadir, I. (2003). The Almajiri System of Education in Nigeria Today. A Paper Presented at the 21st Convocation Ceremony of Bayero University Kano. Retrieved from: http://www.gamji.com/article5000/NEWS5956.htm.

Abdulqadir, M. (2014). An Analytical Study of The Contributions of Sheikh Ibrahim Jalo Jalingo to The Development of Da'awah In Taraba State. $M A$ Dissertation (unpublished). Dept of Islamic Studies and Shariah, Bayero University Kano.

Babajo, H. H., Jamaluddin, Z., \& Hamid, S. A. (2017). The Challenges of Tsangaya Quranic Schools in Contemporary Societies: A study of Kano State Nigeria. Asian Journal of Multidisciplinary Studies, 5(6), 243-250.

Bakewell, O., \& De Haas, H. (2007). African Migrations: Continuities, Discontinuities and Recent Transformations. In African alternatives (pp. 95-117): Brill.

Fuseini, T. (2016). The Experiences of Muslim Child Beggars in Dagbon of Northern Ghana: An Exploratory Study from The Perspective of Salutogenesis. The University of Bergen.

Gada, A. M. (2010). A Short History of Early Islamic Scholarship in Hausaland: AM Gada.

Gbadamosi, T. G. O. (1978). The growth of Islam among the Yoruba, 1841-1908. (Ibadan History Series.) Atlantic Highlands, N.J.: Humanities Press.

Hoechner, H. (2013). Searching for Knowledge and Recognition: Traditional Qur'anic Students (Almajirai) in Kano, Nigeria. French Institute for Research in Africa/InstitutFrançais de Recherche en Afrique (IFRA-Nigeria).

Imam, Y. (2002). Appraisal of the Historical Development of traditional Qur'anic Schools in Northern Nigeria. Unpublished PGDE project. Kano: Federal College of Education. 
Kabir, M., Iliyasu, Z., Abubakar, I. S., \& Ahmad, D. Z. (2005). Medico-Social Problems of Itenerant Qur'anic Scholars in Kano. Nigerian Journal of Paediatrics, 32(1), 15-18. Retrieved from http:/ / www.njpaediatrics.com/v32n1y05content.html

Muhammad, R., Yusuf, A., Bello, M. B. (2013). Teachers and Parents' Assessment of the Inclusive Education of the Almajiri and Education for All in Nigeria. Journal of Resourcefulness and Distinction, 6(1), 1-11.

National Council for the Welfare of the Destitute. (2001). Almajiri and Qur'anic Education. Kaduna. Nigeria: Rishab Printing Press.

Odumosu, O., Odekunle, S., Bolarinwa, M., Taiwo, O., Ajala, A., Alonge, S. K., Akujobi, C. (2013). Manifestations of the Almajirai in Nigeria: Causes and Consequences: Nigerian Institute of Social and Economic Research.

Okugbeni, R. (2013). Basic Education and the Rights of the Almajiri Child, the Rhetoric of Universalism in Nigeria. MA Dissertation. Hague: Masters of Arts in Development Studies.

Otu, J. O. (2006). Portrait of the Almajiri: A Study of Their Daily Activities in Painting. Doctoral Dissertation (unpublished). Department of Fine Arts Ahmadu Bello University Zaria.

Ozigi, A., \& Ocho, L. (1981). Education in Northern Nigeria Winchester. London: Allen \& Unwin.

Shehu, S. (2003). The Integration Project and the Future of Qur'anic/Islamiyyah Schools in Northern Nigeria: Issues and Challenges. Paper Presented at The Forth Northern States Education Pre-Summit Workshop Organized by Northern Education Research Project. (Nerp), Arewa House Kaduna.

Shehu, S. (2006). Improving Qur'anic Tsangaya Education in Nigeria: Trends, Issues, Challenges and the Way Forward. Paper Presented at The Workshop Organized by Borno State Agency for Mass Education. 2nd - 5th May 2006.

Taiwo, F. J. (2013). Transforming the Almajiri Education for the Benefit of the Nigerian Society. Journal of Educational and Social Research, 3(9), 67-72. https://doi.org/10.5901/jesr.2013.v3n9p67

Umar, M. S. (2003). Profiles of New Islamic Schools in Northern Nigeria. Maghreb Review, 28(23), 146-169.

Van Bruinessen, M. (2008). Traditionalist and Islamist Pesantrens in Contemporary Indonesia. in Farish A. Noor, Yoginder Sikand, Martin van Bruinessen (eds), The Madrasa in Asia, Political Activism and Transnational Linkages (pp. 217-245). Amsterdam University Press.

Yola, J. (2002). A Comparative Analysis Between Traditional Islamic Institutions and Government Islamic Schools in Some Northern States of Nigeria. Paper presented at the International Seminar jointly organized by Arab League Educational, Scientific and Cultural Organization and the World Islamic Call Society, Bayero University, Kano.

Yousif, A. F. (2000). Religious Life and Institutions in Brunei. ISIM Newsletter, 5/00, 16. https://openaccess.leidenuniv.nl/handle/1887/17397.

Yusha'u, M. A, Tsafe, A., Babangida, S., \& Lawal, N. (2013). Problems and Prospects of Integrated Almajiri Education in Northern Nigeria. Scientific Journal of Pure and Applied Sciences, 2(3), 125-134. 